\title{
A PARAMETRIC STUDY OF CODE-BASED PERFORMANCE LIMITS FOR WIDE BEAMS
}

\author{
Erkan Töre \\ Department of Civil Engineering, Balikesir University, Turkey, Research Assistant \\ Talip Demiral \\ Department of Civil Engineering, Balikesir University, Turkey, student
}

\begin{abstract}
In this study, we compared the performance limits of building codes and assessed whether these limits could be applied to wide beams. We performed a parametric study, investigating the longitudinal reinforcement ratio, beam width, steel class, and type and spacing of the transverse reinforcement. We obtained the following results from these analyses: Increasing the longitudinal reinforcement ratio reduced the deformation limit corresponding to code-based performance limits. Changing the confinement properties significantly affected the TEC 2007 and ASCE/SEI 41 limits. The performance limits defined by EC8 and ASCE/SEI 41 had similar corresponding plastic deformations, lower than those corresponding to the TEC 2007 strain-based damage limits. The results show that assessing the performance of wide beams by using the performance limits from different codes could produce contradictory results.
\end{abstract}

Key words: wide beams, performance limits, seismic codes, plastic rotation

\section{PARAMETARSKA STUDIJA GRANIČNIH STANJA PONAŠANJA PREMA NORMAMA ZA ŠIROKE GREDE}

Sažetak: U radu smo usporedili granična stanja ponašanja u građevinskim normama i procijenili mogu li se primijeniti na široke grede. Proveli smo parametarsku studiju varirajući omjer armiranja uzdužnom armaturom, širinu grede, klasu čelika i vrstu i razmak poprečne armature. Na osnovi provedenih analiza dobili smo sljedeće rezultate: povećanje omjera armiranja uzdužnom armaturom smanjuje graničnu deformaciju koja odgovara graničnom stanju ponašanja prema normi. Promjena karakteristika ovijanja značajno utječe na granične vrijednosti prema TEC 2007 i ASCE/SEI 41. Granična stanja ponašanja, definirana prema EC8 i ASCE/SEI 41, imala su slične odgovarajuće vrijednosti plastičnih deformacija, niže nego one koje odgovaraju TEC 2007 graničnom oštećenju uzrokovanom deformacijama. Rezultati pokazuju da procjena ponašanja širokih greda, koristeći granična stanja ponašanja iz različith normi, može proizvesti proturječne rezultate.

Ključne riječi: široke grede, granična ponašanja, norme za proračun konstrukcija na potresna djelovanja, plastična rotacija 


\section{Introduction}

Reinforced concrete $(\mathrm{RC})$ buildings with a one-way joist slab system are very common in Mediterranean countries such as Spain, Italy, and Turkey. This slab system provides an inexpensive, flat surface for buildings. The RC beams of these buildings are wider than ordinary frame beams, and they are usually only as deep as the slab. Buildings constructed with these wide, shallow beams have relatively low lateral stiffness, causing them to have been extensively damaged in past earthquakes. Regardless of their inadequate earthquake performance, buildings with wide beams are not significantly limited in Turkish Earthquake Code (TEC) 2007 [1]. According to these codes, buildings can be constructed in any seismic region if all of their structural components have high ductility. Because of these loose restrictions, many buildings have been constructed in regions with high seismic activity. The seismic reliability of these building should be thoroughly researched.

In the last two decades, many methods have been developed to evaluate the earthquake performance of buildings. Strength-based linear analysis and displacement-based nonlinear analysis are recommended in modern codes. Because of widely available computational power, nonlinear structural analysis methods are widely used to assess the performance of existing buildings, and they will be used to design new earthquakeresistant buildings in the near future. By considering the nonlinear behavior of the structure, these methods provide detailed information about its earthquake response. Nonlinear static and nonlinear dynamic time history analysis have been proposed for assessing whether buildings perform to code standards.

The performance of a building under earthquake excitation combines the performance (deformation level) of its structural and non-structural components. To determine the performance level of structural components, one can use nonlinear structural analysis to model their deformation, and then compare those simulations with the deformation (performance) limits proposed by codes. The distribution and concentration of damaged components in a structural system demonstrate its performance level.

Existing buildings are assessed and retrofitted according to performance standards described in Eurocode 8 [2], ASCE/SEI 41 [3], and TEC 2007 [1], which recommend linear and nonlinear analysis. These codes define the performance of structural components by using different deformation criteria. For beams in which flexure dominates, Eurocode 8 [2] uses the chord rotation angle of the beam, ASCE/SEI 41 uses the plastic rotation of the beam end [3], and TEC 2007 uses the material strains at the critical sections of extreme concrete compression fibers [1]. These differences among definitions lead to differences in performance levels of similar structural components. Also, these limits mainly come from experiments with ordinary frame members, so the compliance of wide beams with these limits may differ and should be investigated.

\section{Code Performance Limits}

Generally, building codes have defined three discrete damage (performance) limits and two performance ranges for flexure-dominant ductile members, as shown in Fig. 1. In ASCE/SEI 41 [3], the Performance Levels are Immediate Occupancy (IO), Life Safety (LS), and Collapse Prevention (CP). In EC8 [2], the limits are Damage Limitation (DL), Significant Damage (SD), and Near Collapse (NC). In TEC 2007 [1], the damage limits are the Minimum Damage Limit (MD), Safety Limit (SL), and Collapse Limit (CL).

\subsection{Eurocode 8 Performance Limits}

In Eurocode 8 [2], the deformation capacity of beams, columns, and walls is defined by the chord rotation $\theta$ : the angle between the tangent to the axis at the yielding end and the chord connecting that end with the end of the shear span (the point of contraflexure). The chord rotation also equals the element drift ratio: the deflection at the end of the shear span with respect to the tangent to the axis at the yielding end, divided by the shear span. The state of damage in a member is defined by three Limit States: Damage Limitation (DL), Significant Damage (SD), and Near Collapse (NC). 


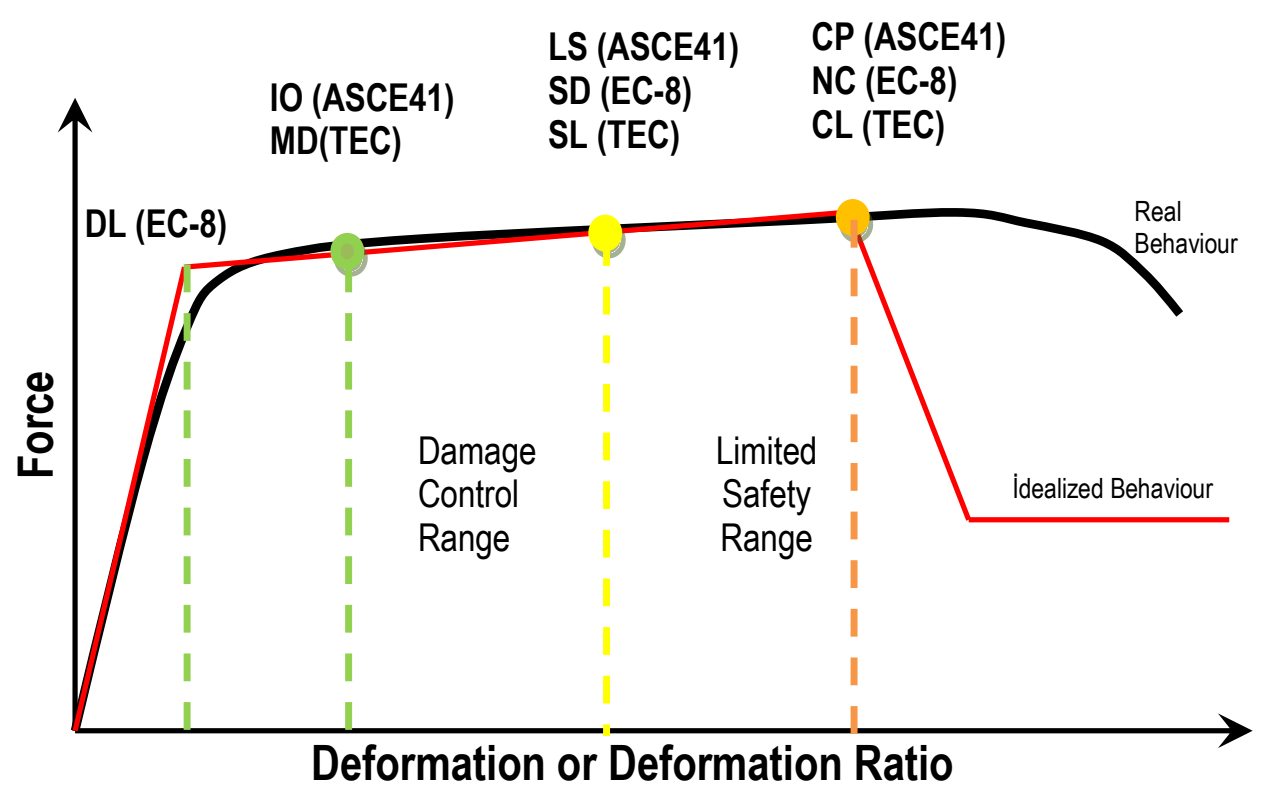

Figure 1. Performance limits for RC components

\subsubsection{Limit State of Near Collapse (NC)}

The total chord rotation capacity (elastic plus inelastic) at the ultimate $\theta_{u m}$ of concrete members under cyclic loading can be calculated from the following expression:

$$
\theta_{u m}=\frac{1}{\gamma_{e l}} 0,0016 \cdot\left(0,3^{v}\right)\left[\frac{\max \left(0,01 ; \omega^{\prime}\right)}{\max (0,01 ; \omega)}\right]^{0,225}\left(\min \left(9 ; \frac{L_{v}}{h}\right)\right)^{0,35}{ }_{25}^{\left(\alpha \rho_{s x} \frac{f_{y w}}{f_{c}}\right)}\left(1,25^{100 \rho_{d}}\right)
$$

where $y_{e l}$ is 1.5 for primary elements and 1.0 for secondary elements, $h$ is the depth of the cross-section, $v=$ $\mathrm{N} / \mathrm{bh} \mathrm{f}_{c}$ (where $b$ is the width of the compression zone and $N$ is the axial force, positive for compression), $\omega$ and $\omega$ ' are respectively the mechanical reinforcement ratio of the longitudinal tension (including the web reinforcement) and compression reinforcement, $f_{c}$ is the concrete compressive strength (MPa), $L_{v}=M / V$ is the ratio of moment to shear at the end section, $\rho_{s x}=A_{s x} / s_{h} b_{w}$ is the ratio of the transverse steel parallel to the direction of loading $x\left(s_{h}=\right.$ stirrup spacing), $\rho_{d}$ is the diagonal reinforcement steel ratio (if any) in each diagonal direction, and $\alpha$ is the confinement effectiveness factor. The plastic part of the chord rotation capacity of concrete members under cyclic loading can be calculated from the following expression:

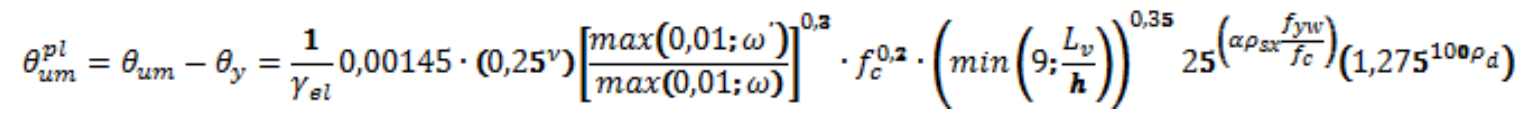

\subsubsection{Limit State of Significant Damage (ND)}

The chord rotation capacity corresponding to significant damage $\theta_{S D}$ is $75 \%$ of the ultimate chord rotation $\theta_{u m}$ given by Eq. (1).

\subsubsection{Limit State of Damage Limitation (DL)}

The capacity for this Limit State, is the yielding bending moment under the design axial load. The corresponding capacity is given by the chord rotation at yielding $\theta_{y}$, evaluated for beams using the following equation: 


$$
\theta_{y}=\Phi_{y} \frac{L_{v}+a_{v} z}{\mathbf{3}}+0,0014\left(1+1,5 \frac{\boldsymbol{h}}{L_{v}}\right)+\frac{\varepsilon_{y}}{d-d^{y}} \frac{d_{b L} f_{y}}{\mathbf{6} \sqrt{f_{c}}}
$$

where $\Phi_{y}$ is the yield curvature, $\alpha_{v} z$ is the tension shift of the bending moment diagram, $d_{b}$ is the (mean) diameter of the tension reinforcement, and $z$ is the internal lever arm. $\alpha_{v}=1$ if shear cracking is expected to precede flexural yielding, otherwise $\alpha_{v}=0$. The first term in Eq. (3) accounts for flexure, the second term accounts for shear deformation, and the third accounts for the bond slip of the bars.

\subsubsection{ASCE/SEI 41 Performance Limits}

In ASCE/SEI 41 [3], the performance criteria for flexure-dominant RC beams is the rotation of the plastic hinge at the component end. Table 1 gives the plastic rotation limits for flexure-dominant beams. These limits vary depending on $\left(\rho-\rho^{\prime}\right) / \rho_{b}$ (where $\rho$ is the tension reinforcement ratio, $\rho^{\prime}$ is the compression reinforcement ratio, and $\rho_{b}$ is the balanced reinforcement ratio) as well as the confinement of the plastic hinge region and normalized shear stress $\left(V / b_{w} d f_{c}\right)$ in the component. The confinement of the plastic hinge region is classified as conforming (C) and nonconforming (NC). A component is considered conforming if its hoops are spaced less than one third of the effective depth in the plastic hinge region and the strength provided by the hoops is at least three fourths of the design shear. Otherwise, the component is considered nonconforming.

Table 1. ASCE/SEI 41-06 Performance Limits [3]

\begin{tabular}{|c|c|c|c|c|c|c|c|}
\hline \multirow{5}{*}{$\left(\rho-\rho^{\prime}\right) / \rho_{b}$} & \multirow{5}{*}{ Tran. Reinf. } & \multirow{5}{*}{$V / b_{w} d f_{c}$} & \multicolumn{5}{|c|}{ Acceptable Plastic Hinge Rotation (rad) } \\
\hline & & & \multicolumn{5}{|c|}{ Performance Level } \\
\hline & & & \multirow[b]{3}{*}{10} & \multicolumn{4}{|c|}{ Component Type } \\
\hline & & & & \multicolumn{2}{|c|}{ Primary Component } & \multicolumn{2}{|c|}{ Secondary Componen } \\
\hline & & & & LS & $\mathrm{CP}$ & LS & $\mathrm{CP}$ \\
\hline$\leq 0.0$ & C & $\leq 0.25$ & 0.010 & 0.02 & 0.025 & 0.02 & 0.05 \\
\hline$\leq 0.0$ & C & $\geq 0.50$ & 0.005 & 0.01 & 0.02 & 0.02 & 0.04 \\
\hline$\geq 0.5$ & C & $\leq 0.25$ & 0.005 & 0.01 & 0.02 & 0.02 & 0.03 \\
\hline$\geq 0.5$ & C & $\geq 0.50$ & 0.005 & 0.005 & 0.015 & 0.015 & 0.02 \\
\hline$\leq 0.0$ & NC & $\leq 0.25$ & 0.005 & 0.01 & 0.02 & 0.02 & 0.03 \\
\hline$\leq 0.0$ & NC & $\geq 0.50$ & 0.0015 & 0.005 & 0.01 & 0.01 & 0.015 \\
\hline$\geq 0.5$ & NC & $\leq 0.25$ & 0.005 & 0.01 & 0.01 & 0.01 & 0.015 \\
\hline$\geq 0.5$ & NC & $\geq 0.50$ & 0.0015 & 0.005 & 0.005 & 0.005 & 0.01 \\
\hline
\end{tabular}

\subsubsection{Turkish Earthquake Code 2007 Performance Limits}

Different from the other codes, the Turkish Earthquake Code 2007 [1] evaluates the performance of RC components using the strain demands of concrete in compression and steel in tension [1]. The plastic curvature demands $(\phi)$ at the component plastic hinge are calculated by using Eq. (4) from the plastic hinge rotations $\left(\theta_{p}\right)$ obtained from nonlinear analysis. The total curvature demand $\left(\phi_{t}\right)$ of the plastic region is the sum of elastic $\left(\phi_{y}\right)$ and plastic curvature $\left(\phi_{p}\right)$ demands, as shown in Eq. (5). The concrete compressive and steel tensile strain demands, which sum to the calculated total curvature demand, at the plastic regions are calculated from the moment-curvature diagrams of the critical section [4]. These diagrams are obtained by using the appropriate stress-strain models for concrete and steel. Unconfined and confined concrete models should be used for the cover concrete (outside confinement) and core concrete (inside confinement), respectively. The steel model 
should also consider strain hardening after yielding. Table 2 compares the calculated strain demands with the damage limits to determine the damage states of the member.

$$
\begin{gathered}
\phi_{P}=\frac{\theta_{p}}{l_{p}} \\
\phi_{T}=\phi_{P}+\phi_{Y}
\end{gathered}
$$

Table 2. TEC 2007 Performance Limits [1]

\begin{tabular}{lccc}
\hline \multicolumn{1}{c}{ Strain Type } & $\begin{array}{c}\text { Minimum Damage Limit } \\
(\mathrm{MD})\end{array}$ & Safety Limit $(\mathrm{SL})$ & Collapse Limit $(\mathrm{CL})$ \\
\hline Cover Concrete Strain $\left(\varepsilon_{c u}\right)$ & 0.0035 & - & - \\
\hline Core Concrete Strain $\left(\varepsilon_{c g}\right)$ & - & $0.0035+0.01\left(\rho_{s} / \rho_{s m}\right) \leq 0.0135$ & $0.004+0.014\left(\rho_{s} / \rho_{s m}\right) \leq 0.018$ \\
\hline Steel Strain $\left(\varepsilon_{s}\right)$ & 0.01 & 0.04 & 0.06 \\
\hline
\end{tabular}

$\rho_{s}$ : Ratio of existing confinement reinforcement at the section

$\rho_{\text {sm: }}$ Ratio of confinement reinforcement required by the TEC 2007 code

\section{Comparison of Code Limits for Wide Beams}

To compare the performance limits of the codes and to evaluate whether these limits are appropriate for wide RC beams, we performed a parametric study. To compare the limits set in the codes, we converted the deformation limits to the plastic rotation of the plastic region. The ASCE/SEI 41 [3] deformation limits directly give the plastic rotation, as shown in Table 1. We calculated the plastic rotations corresponding to the Eurocode 8 [2] limits by using an empirical equation, Eq. (2). We performed conventional section analyses and obtained plastic curvatures from Eq. (5) corresponding to the strain limits in TEC 2007 [1]. To obtain the plastic rotations corresponding to the strain limits, the plastic curvatures were multiplied by the plastic hinge length. Using the definition in TEC 2007 [1], we considered the plastic hinge length as half the beam height. The beam sections were analyzed using the CUMBIA sectional analysis program [5]. To obtain moment curvature diagrams, we used the material models suggested by Mander et al. [6, 7]. Details of the theory and application of this analysis are described in [5].

\section{Table 3. Parameters of beam sections}

\begin{tabular}{cccccccc}
\hline $\begin{array}{c}\text { Section } \\
\text { No. }\end{array}$ & $h(\mathrm{~cm})$ & $b_{w}(\mathrm{~cm})$ & $f_{c}(\mathrm{MPa})$ & $f_{y}(\mathrm{MPa})$ & Trans. Reinf. Type & $s(\mathrm{~cm})$ & $\left(\rho-\rho^{\prime}\right) / \rho_{b}$ \\
\hline 1 & 32 & 60 & 20 & 420 & Single Hoop & 8 & $0.0-1.0$ \\
2 & 32 & 70 & 20 & 420 & Single Hoop & 8 & $0.0-1.0$ \\
3 & 32 & 80 & 20 & 420 & Single Hoop & 8 & $0.0-1.0$ \\
4 & 32 & 60 & 20 & 420 & Double Hoop & 8 & $0.0-1.0$ \\
5 & 32 & 60 & 20 & 420 & Double Hoop & 12 & $0.0-1.0$ \\
6 & 32 & 60 & 20 & 420 & Double Hoop & 16 & $0.0-1.0$ \\
7 & 32 & 60 & 20 & 420 & Single Hoop & 16 & $0.0-1.0$ \\
8 & 32 & 60 & 20 & 220 & Single Hoop & 8 & $0.0-1.0$ \\
\hline
\end{tabular}


Because it greatly affects the ductility of RC beams, we chose the longitudinal reinforcement ratio $\left(\left(\rho-\rho^{\prime}\right) / \rho_{b}\right)$ as the main parameter of the present study. We studied wide beam sections with longitudinal reinforcement ratios ranging from 0.00 to 1.00 . We also considered the beam width, steel quality, and the type and spacing of the transverse reinforcement. Table 3 gives the parameters of the beam sections we studied. For all beam sections we studied, the section height was $32 \mathrm{~cm}$, which is often preferred in practice, and the shear span was $200 \mathrm{~cm}$.

\subsection{Effect of Beam Width on Performance Limits}

Figures 2-4 give the calculated code-based plastic rotation limits for sections 1, 2, and 3 from Table 3 . The EC8 damage limits were slightly affected by the beam width. In contrast, the strain-based limits from TEC 2007 were not affected by this parameter, and the ASCE/SEI 41 limits for flexure-dominant beams are independent of beam width.

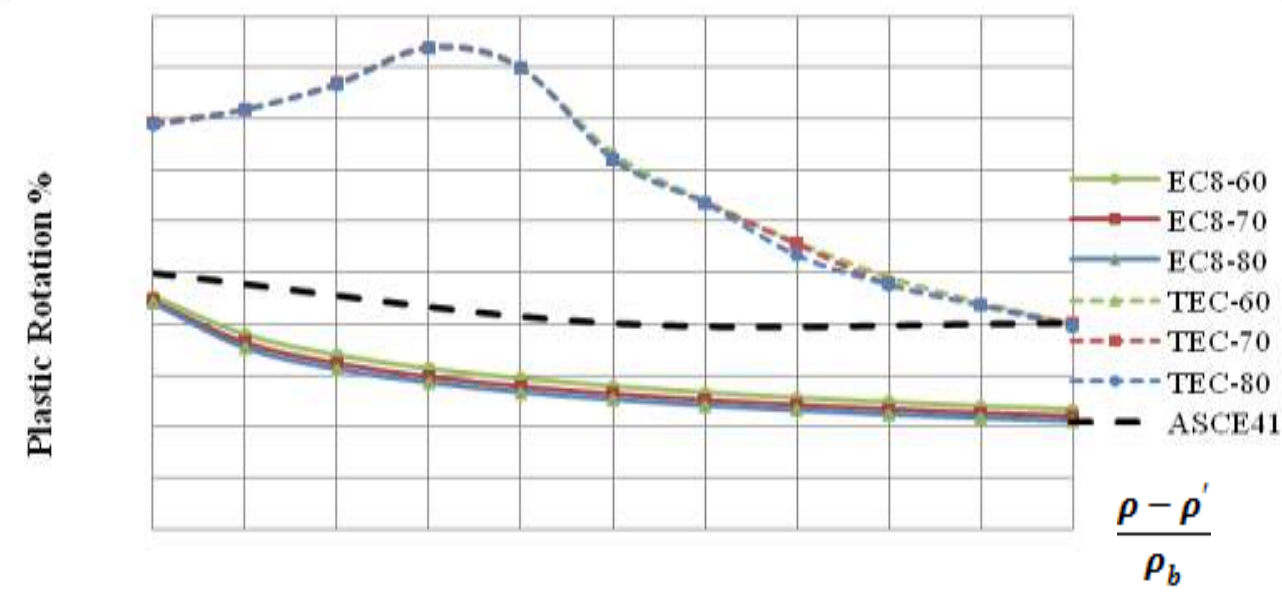

Figure 2. Plastic rotation of CP (ASCE41), NC (EC8), and CL (TEC) limits for different beam widths

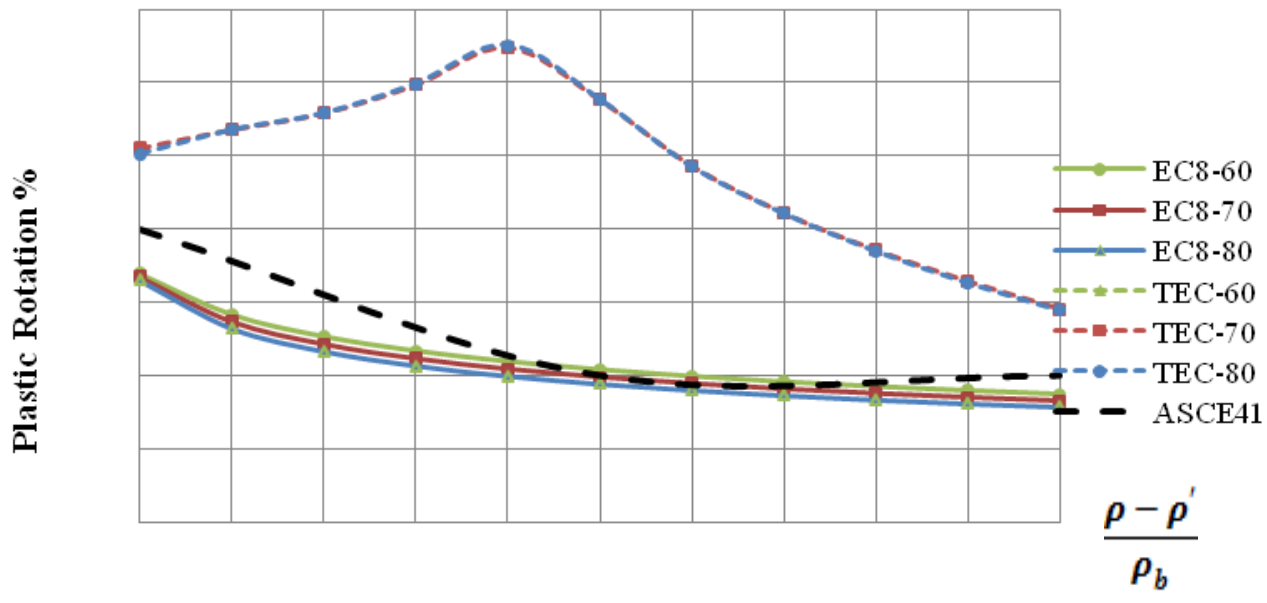

Figure 3. Plastic rotation of LS (ASCE41), SD (EC8), and SL (TEC) limits for different beam widths 


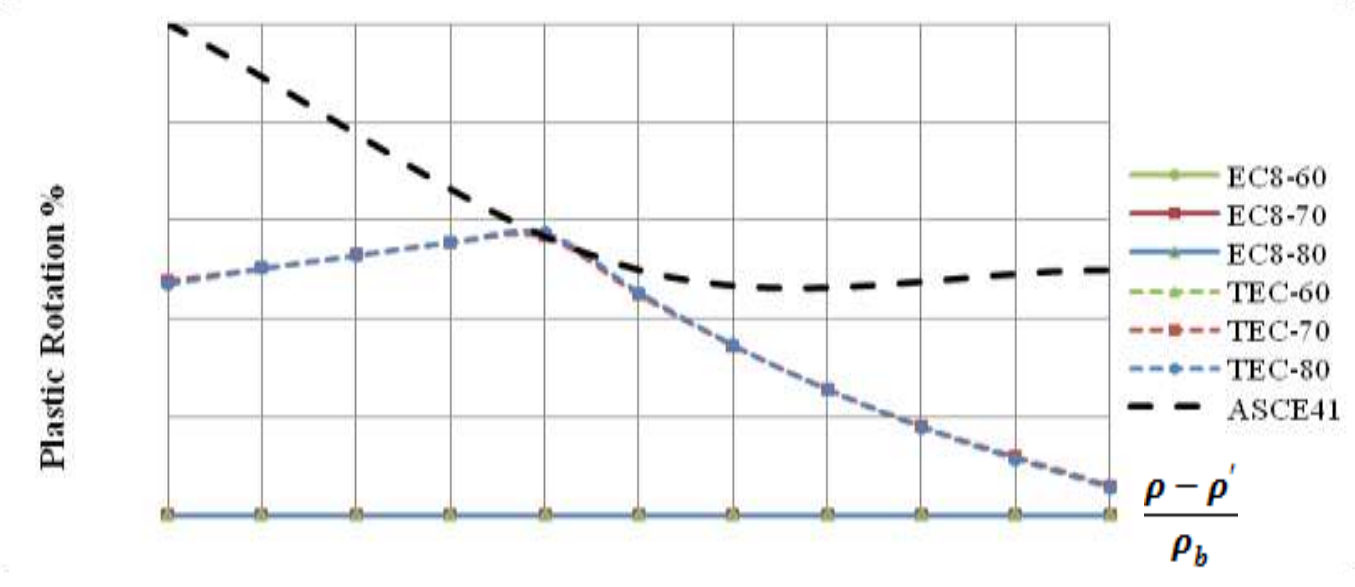

Figure 4. Plastic rotation of IO (ASCE41), DL (EC8), and MD (TEC) limits for different beam widths

\subsection{Effect of Transverse Reinforcement Spacing on Performance Limits}

The spacing of transverse reinforcement greatly affected the ductility of the RC components. Figures 5-7 show the plastic rotations corresponding to the damage limits for sections 4-6 from Table 3 . Though the transverse reinforcement spacing significantly affected the ductility of RC members, increasing it did not affect the EC8 deformation limits. In contrast, increasing the spacing significantly decreased the TEC 2007 limits. Similar to TEC 2007, increasing the spacing caused the beams to change from confinement class $C$ to NC, decreasing the ASCE/SEI 41 plastic rotation limit.

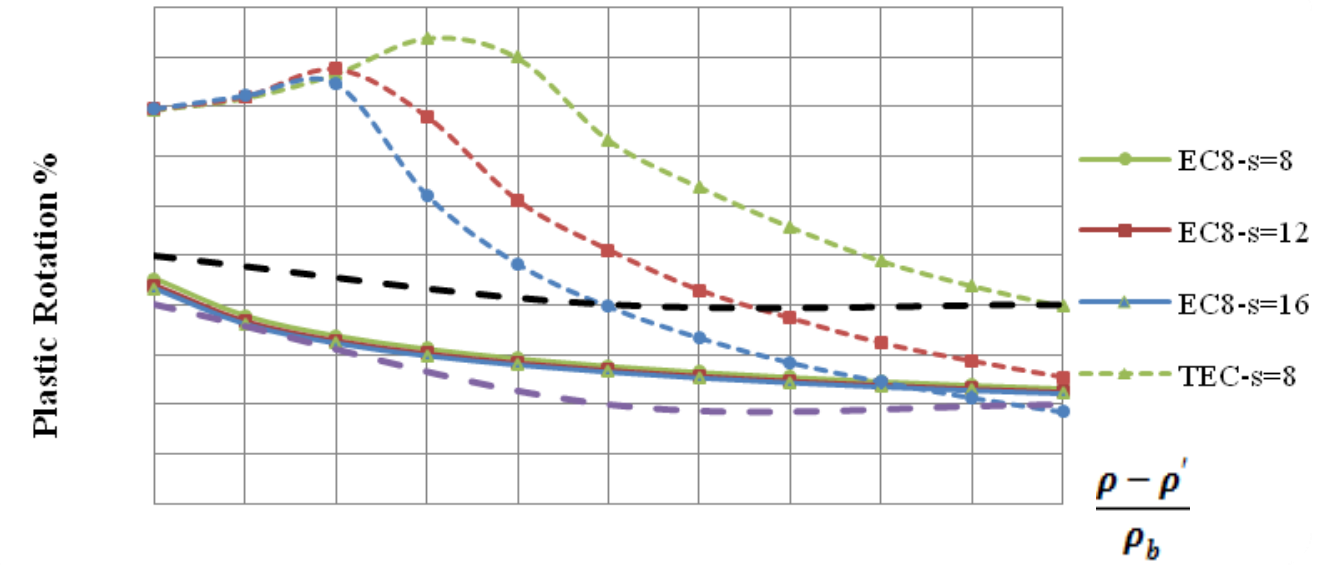

Figure 5. Plastic rotation of CP (ASCE41), NC (EC8), and CL (TEC) limits for different transverse reinforcement spacings 


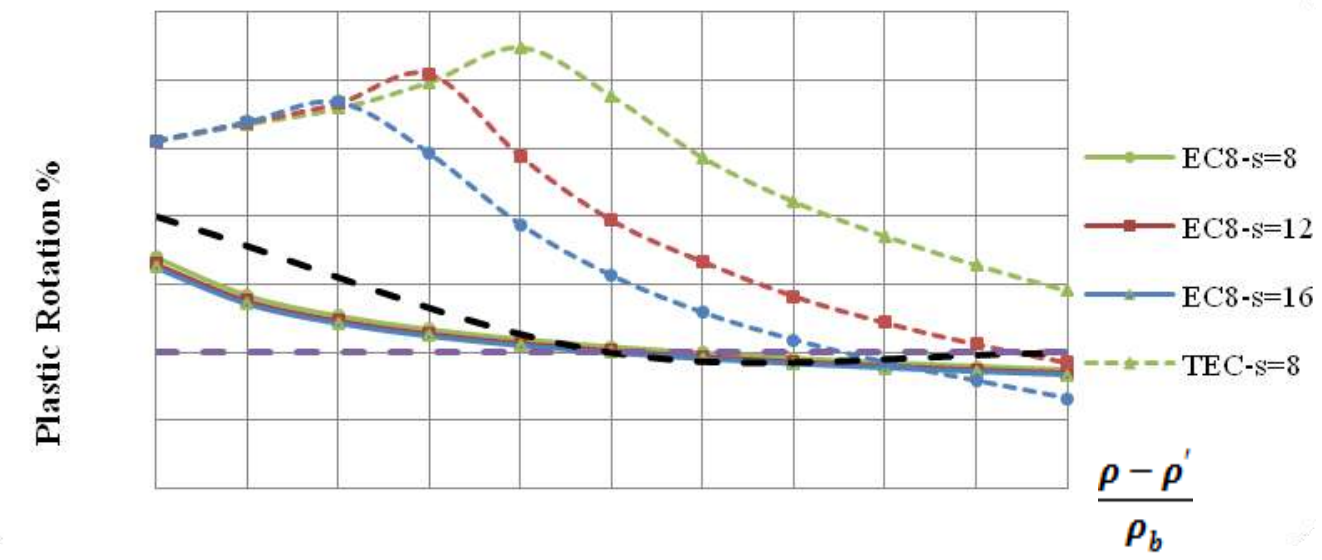

Figure 6. Plastic rotation of LS (ASCE41), SD (EC8), and SL (TEC) limits for different transverse reinforcement spacings

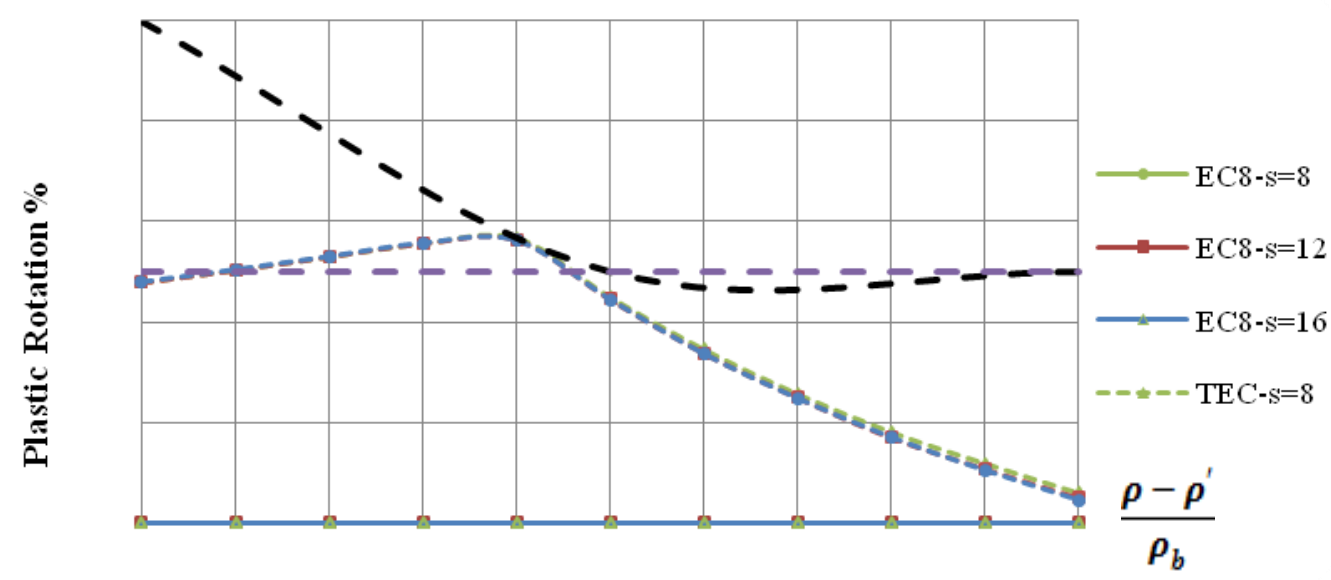

Figure 7. Plastic rotation of IO (ASCE41), DL (EC8), and MD (TEC) limits for different transverse reinforcement spacings

\subsection{Effect of Steel Classes on Performance Limits}

Turkey defines two quality classes of reinforcement steel, S420 and S220, so we only considered these steel classes in the present study (sections 1 and 8 from Table 3). The details of these materials can be found in TEC 2007 [1]. All the building codes investigated in the present study define deformation limits that differ much between different classes of reinforcement steel, as shown in Figures 8-10. Because S220 steel has low yield strength, the shear force resistance of transverse reinforcement decreases and the ASCE/SEI 41 limits for NC components must be accounted for. 


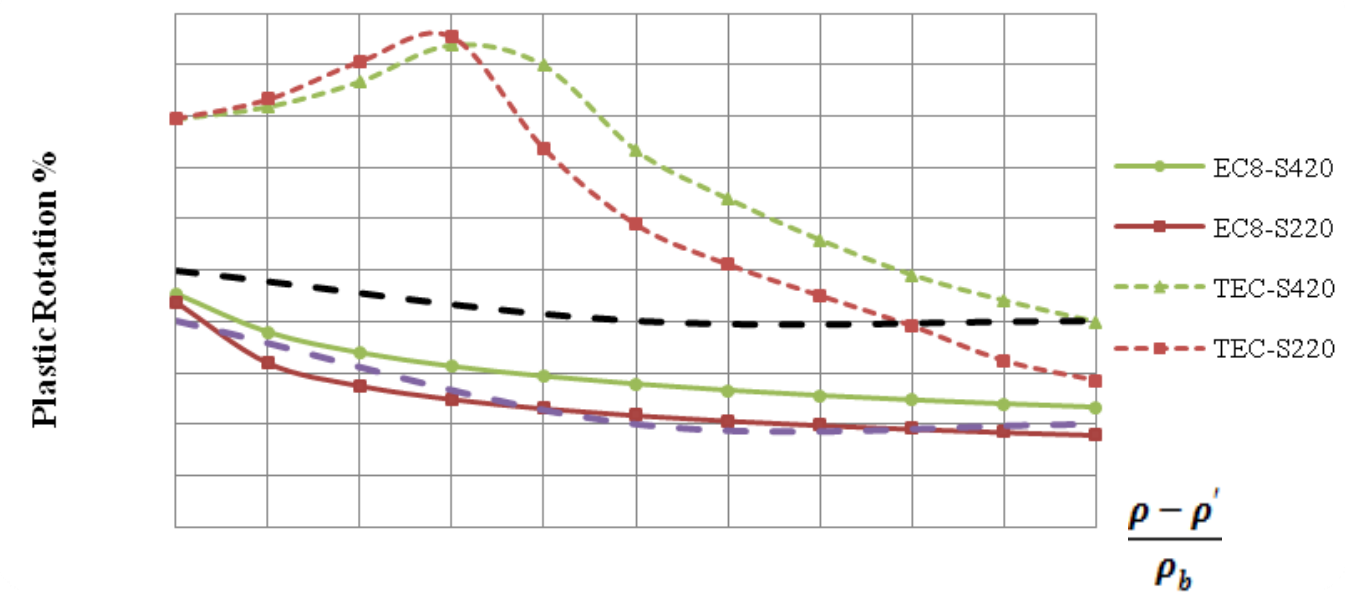

Figure 8. Plastic rotation of CP (ASCE41), NC (EC8), and CL (TEC) limits for different steel classes

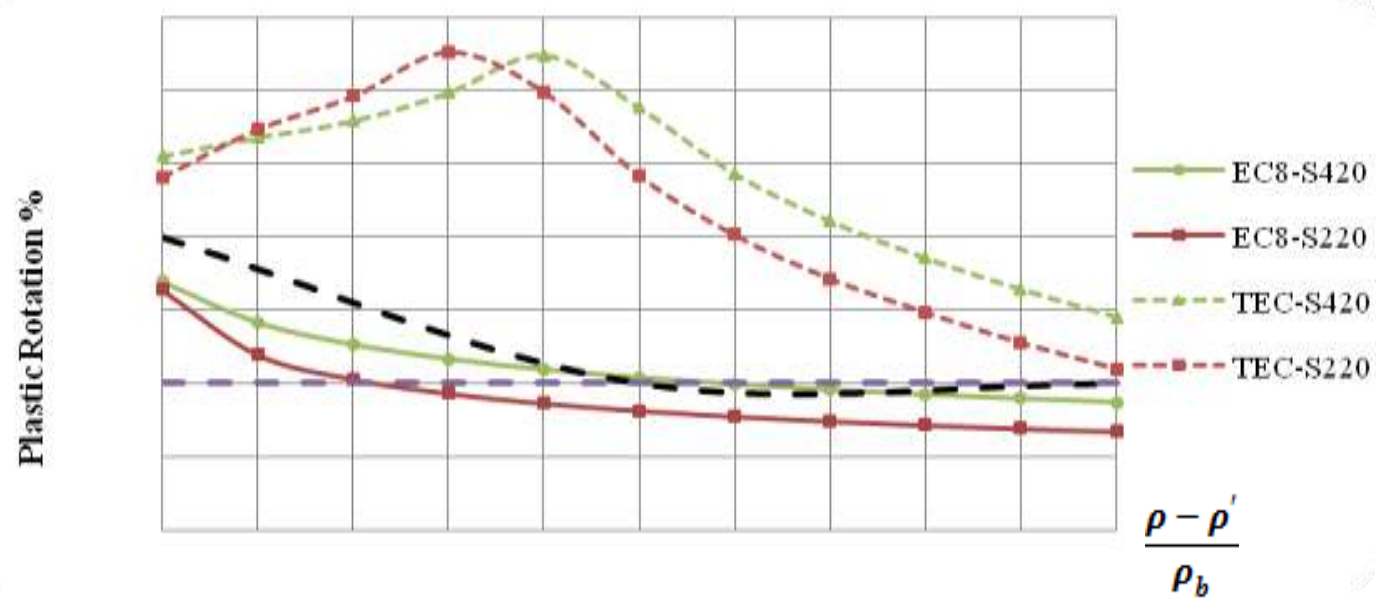

Figure 9. Plastic rotation of LS (ASCE41), SD (EC8), and SL (TEC) limits for different steel classes

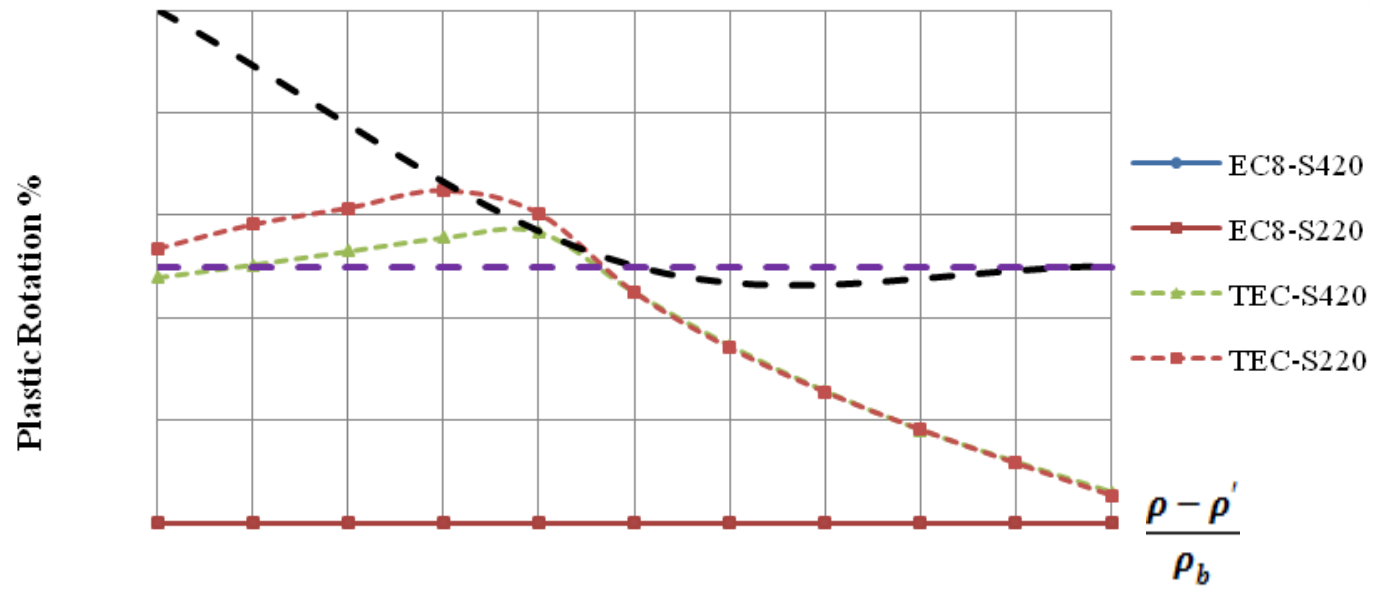

Figure 10. Plastic rotation of IO (ASCE41), DL (EC8), and MD (TEC) limits for different steel classes 


\subsection{Effect of Transverse Reinforcement Type on Performance Limits}

Figures 11-13 show how using a single or double hoop as transverse reinforcement affected the deformation limits (sections 1, 4, 6, and 7 from Table 3). The ASCE/SEI 41 codes determine the confinement class of components by assessing the shear resistance of the transverse reinforcement. The plastic rotation corresponding to the TEC 2007 deformation limits depends much on the type of transverse reinforcement because confinement affects the core concrete strain. Using a closely spaced double hoop increased the EC8 plastic rotation limits, but other arrangements of the transverse reinforcement did not significantly affect these limits.

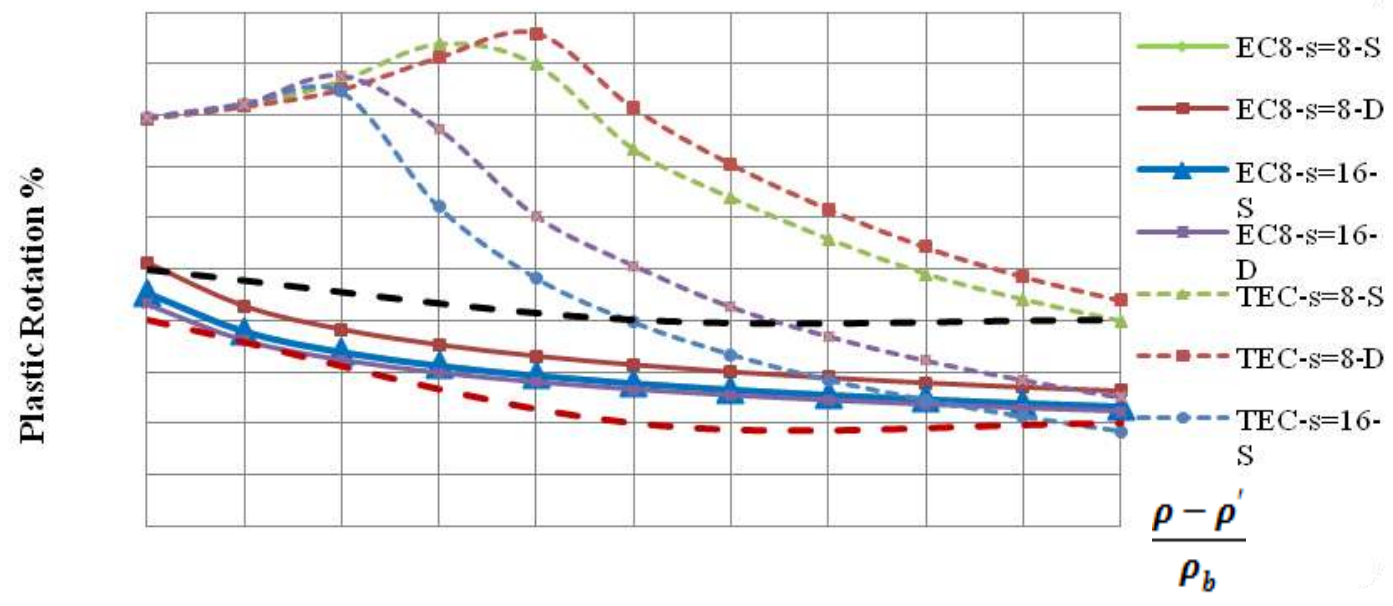

Figure 11. Plastic rotation of CP (ASCE41), NC (EC8), and CL (TEC) limits for different transverse reinforcements

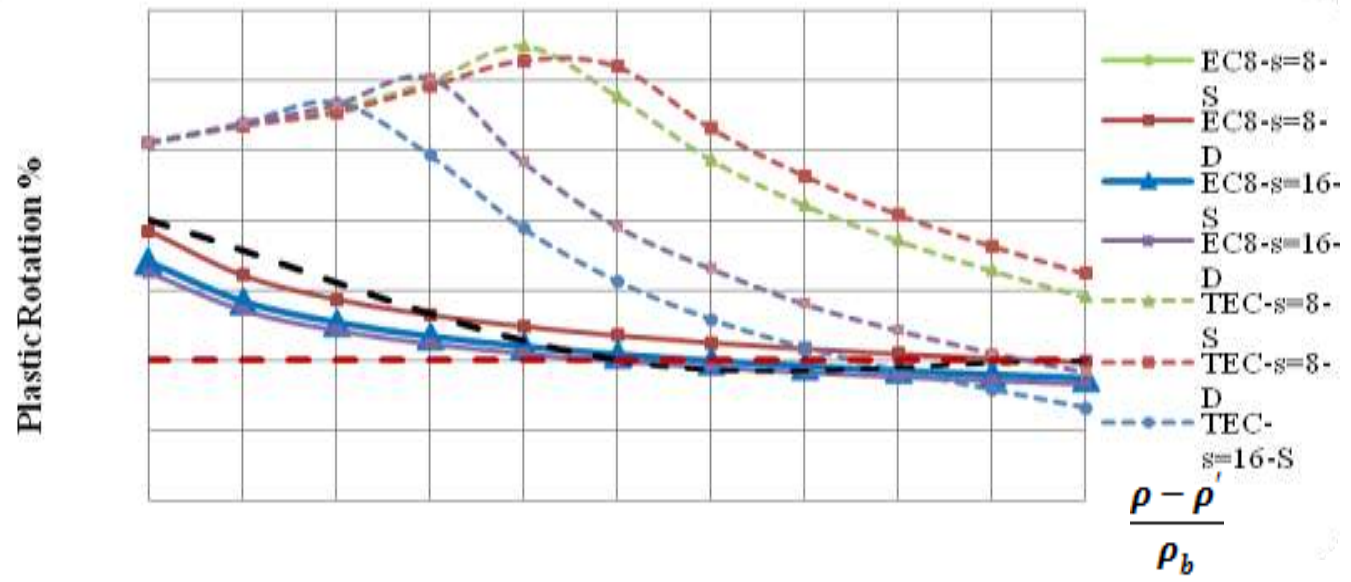

Figure 12. Plastic rotation of LS (ASCE41), SD (EC8), and SL (TEC) limits for different transverse reinforcements 


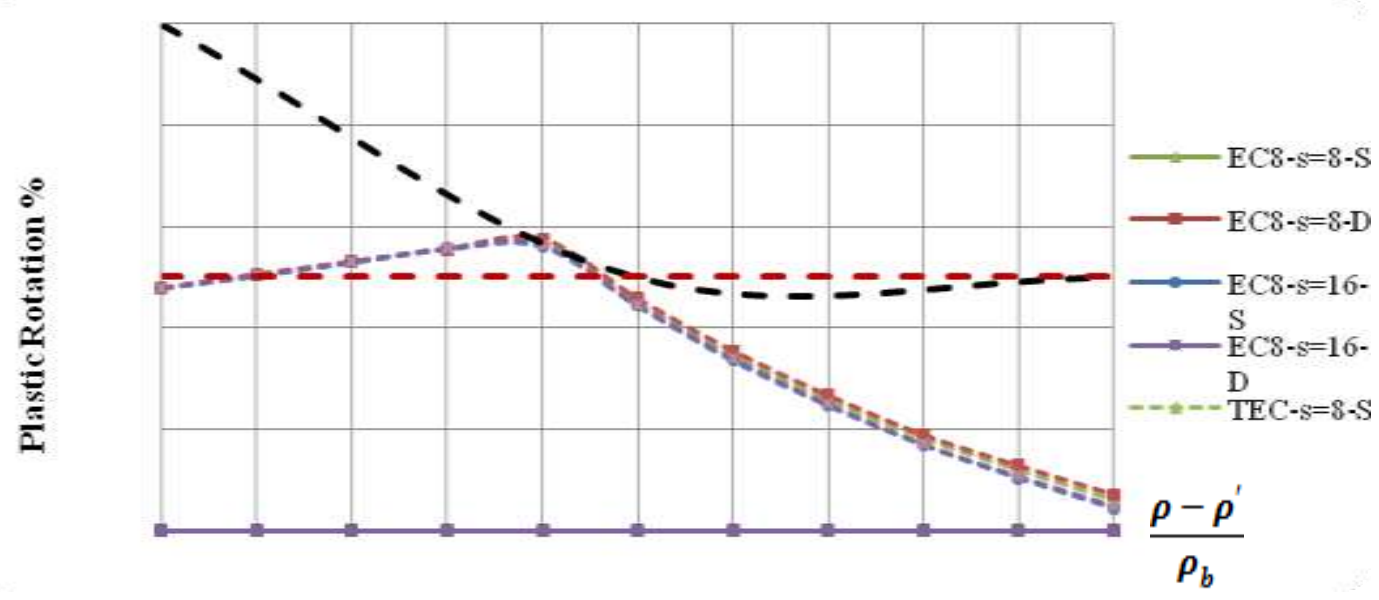

Figure 13. Plastic rotation of LS (ASCE41), SD (EC8), and SL (TEC) limits for different transverse reinforcements

\section{Conclusion}

Modern codes such as ASCE/SEI 41, Eurocode 8, and TEC 2007 include procedures to evaluate the performance of existing buildings. These codes define the performance levels of RC components by using different performance (damage) criteria and limits. In the present study, we investigated the parameters affecting these limits for wide beams and compared the rotation limits of the various codes.

Increasing the longitudinal reinforcement ratio reduced the deformation limits for ASCE/41 and EC8. The strain-based deformation limits of TEC 2007 increased with longitudinal reinforcement ratios of 0.3-0.4, while it decreased at greater values. Parameters related to confinement of the plastic region significantly affected the TEC 2007 limits; these parameters also changed the component confinement class, as defined in ASCE/SEI 41, of the beam specimens. The EC 8 limits were not affected by these parameters, but they were affected by changes in steel class. For all cases, the TEC 2007 material strain-based performance limits corresponded to higher plastic deformation than the other two code limits. Generally, the ASCE/SEI 41 and EC8 performance limits corresponded to similar plastic deformations for wide beams, but these lower deformation values might be conservative for properly detailed ductile RC components.

\section{References}

[1] Turkish Seismic Design Code for Buildings, Specification for Structures to be Built in Disaster Areas. TSC07. Ministry of Public Works and Resettlement, Ankara, Turkey; 2007.

[2] Eurocode 8: Design of Structures for Earthquake Resistance-Part 3: Assessment and Retrofitting of Buildings. BS EN 1998-3. Comité Européen de Normalisation, Brussels, Belgium; 2005.

[3] Seismic rehabilitation of existing buildings. ASCE/SEI 41. American Society of Civil Engineers, Reston, Virginia; 2006.

[4] Kazaz I.; Gulkan P.; Yakut A. 2012: Performance limits for structural walls: An analytical perspective, Engineering Structures, Volume 43, pp. 105-119

[5] Montejo, L.; Kowalsky M. J. 2007: CUMBIA-Set of Codes for the Analysis of Reinforced Concrete Members Theory and User Guide. Constructed Facilities Laboratory, Technical Report No. IS-07-01, NC State University.

[6] Mander J. B.; Priestly M. J. N.; Park R. 1998: Theoretical stress-strain model for confined concrete, ASCE, Volume 114, Issue 8, pp. 1805-1826

[7] Mander, J. B.; Priestley, M. J. N.; Park, R. 1984: Seismic design of bridge pier, Research Rep. 84-02, Dept. of Civ. Eng., University of Canterbury, Christchurch, New Zealand. 